\title{
Polysèmes
}

Revue d'études intertextuelles et intermédiales

$25 \mid 2021$

Lieux revisités

\section{"Something good might rise out of it": Ron Rash presents In the Valley in conversation with Colum McCann}

Frédérique Spill

\section{(2) OpenEdition}

Journals

Electronic version

URL: https://journals.openedition.org/polysemes/9019

DOI: 10.4000/polysemes.9019

ISSN: 2496-4212

Publisher

SAIT

Electronic reference

Frédérique Spill, "'Something good might rise out of it": Ron Rash presents In the Valley in conversation with Colum McCann", Polysèmes [Online], 25 | 2021, Online since 30 June 2021, connection on 11 July 2021. URL: http://journals.openedition.org/polysemes/9019; DOl: https://doi.org/10.4000/polysemes. 9019

This text was automatically generated on 11 July 2021 .

Polysèmes 


\title{
"Something good might rise out of it": Ron Rash presents In the Valley in conversation with Colum McCann
}

\author{
Frédérique Spill
}

\section{AUTHOR'S NOTE}

Transcription, edition and introduction by Frédérique Spill

University of Picardy Jules Verne, Amiens, France

On September 2, 2020, Powell's Books, “one of the world's largest independent bookstores", ${ }^{1}$ based in Portland, Oregon, hosted Ron Rash and Colum McCann on Zoom. At the time, Ron Rash's new collection, In the Valley: Stories and a Novella based on Serena, had just come out. A virtuosic novelist, poet, and story writer, Rash evokes the beauty and brutality of the land, the relentless tension between past and present. In the ten stories of his new collection, he spins a haunting allegory of the times we live inrampant capitalism, the severing of ties to the natural world in the relentless hunt for profit, the destruction of body and soul with pills meant to mute our pain-and yet within this world he illuminates small acts of everyday heroism. In revisiting Serena Pemberton, the eponymous character of his 2008 novel, Rash updates his parable of greed run amok as his deliciously vindictive heroine returns to the North Carolina wilderness she left scarred and desecrated to make one final effort to kill the child that threatens all she has accomplished. Rash is joined in conversation by Colum McCann, National Book Award-winning author of Let the Great World Spin (2009) and, more recently, of Apeirogon (2020).

Rash grew up in Western North Carolina, where his family has lived for generations. The region is the landscape his writing is devoted to, and where his forever fertile imagination sprouts from. Whereas Ron Rash's fiction travels across time from a deeply-rooted regional anchorage, much in the fashion of another Southerner, William 
Faulkner, who developed "his own little postage stamp of native soil" through the apocryphal Yoknapatawpha County, Colum McCann is a free electron of a writer. Born in Dublin in another nation of awe-inspiring writers, McCann has lived in Ireland and Japan; but he has been a New Yorker for decades now: an Irishman in New York, he escapes clear-cut categorizations. This is remarkably exemplified in his latest novel, which retraces the unlikely friendship between Rami Elhanan, an Israeli, and Bassam Aramin, a Palestinian, over years and through harrowing experiences of loss, on both sides of a wall which, halfway through the book, is transcended, if only for a moment, by tightrope walker Philippe Petit, whom McCann's reader already came across in Let the Great World Spin. While in his latest book, In the Valley, Rash writes about Appalachia and how life there reflects universal concerns from within, in Apeirogon McCann daringly and admirably revisits the history of the Israeli-Palestinian conflict from without. Yet, despite what may first appear as obvious divergences, both writers have a great lot in common. They are both tightrope writers, finding a compelling balance in the way they retrace the bleakness of the world while refusing to yield to darkness. The inherent luminosity of their writing ultimately breaks through the dark and conveys a much-needed sense of hope. Neither of them shirks away from the dense intricacies of human motivations: they both embrace the fogginess of perception and feeling so majestically metaphorized in Rash's title novella, "In the Valley", which is, indeed, steeped in fog.

What do two writers talk about when they are brought together? As the following conversation demonstrates, they talk about literature and graciously quote from one another, as well as from the writers they admire. They, of course, talk about the short story, present and past, and about storytelling; they talk about their own work as writers and about outstanding endeavors like Narrative 4 . They talk about the state of the world, about the need to acknowledge confusion and about the way they envision the role of artists today. Mostly, they talk like nobody else does, in a language of their own fraught with images and metaphors; they speak in stories as some speak in tongues.

4 Colum McCann: It's so good to see you, Ron, though tonight, we're joined together by a little bit of grief, a little bit of sadness. Would you care to explain to our listeners how we're joined together that way?

5 Ron Rash: Yes, last week we lost not only one of our best writers, but one of our best people. Randall Kenan, a writer from North Carolina and a long-time friend of ours, passed away suddenly. I talked to him about ten days ago and everything seemed to be going well. He has a book out and the least I can do is tell people about it. It's called If I Had Two Wings, and I'd like to believe that maybe he does now; he deserves them. It's a book of stories that is beautifully done. While some of his work would be labeled literary realism, other times it's a combination of folklore and magical realism: those two trends tend to blur in his work. Randall is a wonderful writer; I will miss him and I don't think anyone can replace exactly who he was.

Colum McCann: I met him ten years ago at the founding of Narrative 4, which brings people from around the world to share stories with one another. He was always at the coalface of things, but always gentle, humble, quiet and brilliant. He talked a lot about stories and storytelling and he also worked in different forms. I don't know if Randall had a chance to read In the Valley in advance, but I hope that with his two wings, he will read it elsewhere. It's an extraordinary book. Congratulations on a very beautiful 
collection of stories. I had a chance the other day just to hide away and sit with these stories and it was one of those moments when I felt the "medicine" of your stories (I think Randall used that expression). I first wanted to ask you about the different forms you use, poetry, novels and short stories, and about how you feel moving between those different universes.

Ron Rash: I think in a novel you have a little leeway: you can wander a bit, maybe let the writing ratchet down occasionally; but in a short story, in a good one at least, you cannot lose focus or take anything out. One wrong sentence in a story can be like a single weak stitch unraveling a whole coat. So, I love that form and I love the particular magic of it. But when I start writing, and this has been true for years, I really don't know where it's going. I always start with an image. Serena began with the image of a woman on horseback; that's all I had. I thought it would be a story and then, in a sense, it is almost as if the story itself demanded more. I've started off novels with a poem. Actually, my first novel was a twelve-line poem and then it became a short story. I had already written two terrible novels and had burned them and now I had this terrible compulsion to try to write another one. Fortunately, I felt this one worked. Where do you begin?

8 Colum McCann: I generally begin with an image too. What is interesting to me is that, as you say, a short story is a universe and a novel is a universe too. It just strikes me that the novel is an expanding universe in the sense that it sends off shrapnel in thousands of different directions. Yes, it doesn't have to be perfect; you can make a mistake in a novel. But a short story is like an imploding universe; it's like this perfect circle that gets tighter and tighter. In there, everything counts. I'm always intrigued why the short story does not get more of a hosanna in the American literary landscape because it's really difficult to achieve a beautifully calibrated short story.

But obviously I can tell you're working and working and working in getting the music of this right. So, can you tell me a little bit more about the process of the short story? How long they might take you? Where the images might arrive from? And whether it's as terrifying to start a short story as it is to start a novel?

Ron Rash: The first thing I would say is that I personally believe that American literature's great gift to world literature is the short story. I think this is what we've done best. We've certainly contributed a lot, not only in this century, but we can go back to Melville, Hawthorne and Poe. So, I think the short story is something we should celebrate because we've done it really well. But it really has its challenges. And I like what you say about music, because it really is there, and in several ways. I'm interested in creating a visual rhythm, which I find particularly effective in short fiction. Those visual echoes become a silent music.

Colum McCann: I may be wrong, but I get the feeling you read your stories aloud.

Ron Rash: I don't read all of them aloud, but whenever I'm stuck in a story or I know something is not quite right and I can't nail it down, I will read it out loud and the ear often knows before the eye. But for me, inside, it's always audible. I hear the sounds as I'm writing, perhaps in part because I'm also a poet.

Colum McCann: It's really obvious to me that you're working on the internal music as contrapuntal in certain ways and you're pushing things to certain edges. But it reminds me I really wanted to talk to you about the link between the music of where you are and the music of where I come from. It seems to me you have so many Irish rhythms 
going on as well. I know that you won the Frank O'Connor award. ${ }^{2}$ I also know that you're hugely popular in Ireland as a writer. I'm wondering if you can make sense of that kinship. I have an inkling myself, but I'd really like to know what you think.

Ron Rash: Yes, it's absolutely there on many levels. Part of it is that many people in the American South were from Ireland. There's a great quote by Graham Green in The Third Man, where a character says: "In Switzerland, they had brotherly love, they had five hundred years of democracy and peace-and what did that produce? The cuckoo clock". Unfortunately, art very often comes from contradiction and turmoil. The religiosity of the two regions and that conjunction of violence come together. What's your view on that? protesting peacefully and engaging with democracy. I think it's going to be really interesting to see what happens with young writers. We're going to have an explosion of different forms of storytelling and storytellers. I think there's going to be a lot of things bubbling up from underneath in the next few years. New ways of talking, new ways of telling, new ways of questioning, breaking down the old rules and the old boundaries. This leads me to your collection which, in a curious way, is about now.

Ron Rash: Absolutely. I was finishing the book when the covid pandemic began, and it certainly had an impact, as did the political turmoil and divisiveness. Writing about the past can be subversive. I think you do this. The reader goes along thinking, well this is the past, this is not my world or concern, and then you hope there's the moment when the reader realizes the story is equally about the present, sometimes even more so than the past. That is certainly true of the first story, "Neighbors".

Colum McCann: There's this Faulkner quote: “The past is never dead. It's not even past". And the fact that when you remember something you remember it in the present and you're not necessarily the same person you were then.

I'd like to get to some of the stories: "Neighbors" is the first story, right? There are ten stories in the collection and we're going to get to Serena eventually later in the conversation. But I had a question for you: on the initial page you have a superb statement, an inscription about fate, that is not ascribed to anybody. It says: "And I do not mean the faith which flees the world, but the one that endures the world and that loves and remains true to the world in spite of all the suffering which it contains for us". Is this Ron Rash?

Ron Rash: No. It's Bonhoeffer. They accidentally left out the attribution. It is his quote.

Colum McCann: It's a great quote. Why do you think it introduces the whole book?

Ron Rash: When I had to decide which stories would go in this collection, I had eighteen to choose from. My idea of a collection is that the sum should always be greater than the individual parts. So, I wanted to set up a particular tone and also a rhythmic movement through time. I wanted to place characters in really tough situations, yet, at the same time, show them doing the best they could. Faulkner has a great quote along that line; he said that "Most men are a little better than their circumstances give them a chance to be". I love that quote and actually I believe it. He does say "most", he does say "a little". I wanted to have hard-won hope in this book.

Colum McCann: "Neighbors" is about contradiction, it is about people not understanding who they were, what their histories were. Could you tell us a little bit about where this story came from? 

was very different from the rest of the South. There was slavery in the Appalachian Mountains, but much less than elsewhere in the South and there was a lot of Union sympathy in the North Carolina Mountains. I have a photograph of one of my relatives who fought in the Civil War and he's wearing a Union uniform. This wasn't unusual. The particular place where the story is set was a Unionist stronghold. So, you have this woman whose husband was killed and he fought for the Confederacy; but of course, she doesn't want any of her neighbors to know this because they've been looking after her and her children and she knows that if they find out, they will be cast out, perhaps worse. Simone Weil talks about contradiction as the lever of transcendence. I think in Apeirogon, that's where you were headed with those two characters, Rami and Bassam, too.

McCann: Sure. Some of my favorite words right now are "I don't know" and "I'm confused". I'm thinking back to the Transcendentalists and also to Whitman: "Do I contradict myself? Very well then I contradict myself, (I am large, I contain multitudes)". One of the things that happen in this country right now, it seems, is that we are afraid of embracing our multitudeousness. What you appear to be doing in this collection, and yes, it's also what I've tried to do in Apeirogon, is to talk about confusion, is to talk about contradiction, is to talk about the bravery of saying: "I don't know". I think this is a particularly important thing today for novelists, especially for contemporary American novelists-for her and him to get up and say: this is messy; enough of all the certitudes; let's talk about the messiness. And immediately, with the opening story of In the Valley, you're dealing with human messiness. This is really about now. This wasn't really a question, but I'd like to know how you feel about the way I read the story.

Ron Rash: You're absolutely right. I think the story shows the danger of tribalism. This woman is in this community in such a horrific situation where there is no clear answer. She does what she has to do in order to survive; but there's a huge cost there as well. I was thinking about this today, actually, thinking about your book. I was remembering when I was a kid one summer: my uncle was working in a field and I was carrying water out to him in these two big buckets. As I was doing it, I could feel the handle going deep into my hand-how hard it was just to keep holding them up. That made me think of your two characters in Apeirogon and what they're doing. One reason why we think writing is valuable is exactly what you've described: this idea of abeyance. Being able to hold two contradictory ideas in your mind and still function is hard. It's hard, not necessarily to balance the two buckets, but to keep from completely dropping one.

Colum McCann: That's beautifully said. What I want to move on to now is the fact that there's a lot of fire in the streets right now, as our friend Randall put it. ${ }^{3}$ There's a lot of fire in the streets. But there's also a lot of fire imagery in the stories that follow "Neighbors". You've been writing about fire before and maybe I'm just getting into it too much; but I really think you are talking about some kind of burning that's going on. Ashes don't return to wood. But how do we re-inspire from the fire back into some place that we can rebuild?

Ron Rash: Yes, that's ultimately how I see forests after fires as, very slowly, sprigs start to grow back up. But you're right: I started off the collection with the burning of the barn, then I ended it with the destruction of this forest. But there's also within that, as you've been pointing out, the possibility that something good might rise out of it.

Polysèmes, 25 | 2021 
That's our hope. I think it's not so much that we get that answer in the books. This might sound pretentious, but I feel my role is more witness than anything.

Colum McCann: That doesn't sound pretentious at all. One of the things I feel about you and a few other writers is that you're not interested in answers whatsoever. You're interested in allowing someone else to pose the questions. Yes, you're witness; but you can only witness if you bring people into new territory, which is what you do with the helicopter story for instance ["Sad Man in the Sky"] and the story about World War Two and the cave paintings ["L'Homme blessé"]. There is a momentum in this book, and you build and you build and you build, and you switch times, and then you go back to Serena. The collection contains a novella and I believe many people will read this book because they want to revisit her. You went back to Serena. Why?

Ron Rash: Oh, I didn't want to. I've always been leery of sequels in movies and novels. I didn't want to write the literary equivalent of "Ghostbusters 2" to me. And I didn't want to write another novel about Serena. But I'd never written a novella and I love the form. Denis Johnson has a wonderful novella entitled Train Dreams. I'd never written a novella. The main impetus was the character, Ross, a minor presence in Serena. You probably know that feeling when certain characters haunt you; they refuse to step offstage. I was compelled to get into his story. But I still needed to create a new architecture to make the novella self-contained, more than a caboose hooked to Serena. Then I realized that if I could make this valley a metaphor for an ark filled with creatures that disembark between chapters I had what I needed. Once again, evoking musical elements, this time a diminishing refrain.

Colum McCann: And you achieve it beautifully. Although the novella gives the sense that ultimately there's nothing more to destroy, I'd like to talk about your optimism. It seems to me you're willing to embrace the cynics, but also beat the cynics because you know what they're talking about. It seems to me that you know the darkness; but something about your work pushes it into the realm of optimism, which is somewhat dangerous since it's much more cool and fashionable to sit in the corner in dark clothes and not wearing your heart on your sleeve. But you kind of wear your heart on your sleeve. So, tell me about that, Ron.

31 Ron Rash: Rilke says "Search into the depths of Things: there, irony never descends". I think you're right: the easy thing is that kind of cynicism and I can be very cynical at times. But the cynicism you speak of is too easy, in art and in life. Maybe we could talk one minute about Narrative 4 , because that first time we exchanged stories among us in Colorado really changed my life.

Colum McCann: Yes, the reason that we know each other is related to Narrative $4^{4}$, a global non-profit network that encourages people, mostly young people, to step into one another's shoes and tell one another's stories. The empathy of telling one another's stories-Ron tells my story, I tell his-turns into action on the ground. Now Narrative 4 is in South Africa, in Ireland, in Mexico. The best way to describe this organization is probably to tell how last year we brought together people from the south Bronx and from eastern Kentucky, which most people think are light years removed. These kids were terrified of one another at first, but that changed when they started telling each other's ordinary stories. First, Rick told Farita's story as a girl wearing a hijab with her air pods underneath it and he starts thinking, oh, that's much more interesting than I thought. Then Farita had to tell the story of Rick who has a shotgun at the back of his truck: why does he have it? Everything is much more complicated than both could ever 
imagine. We are messy and we are complicated. The job of our artists to me is to embrace the messiness of human experience. So much we are faced with now tries to boil things down to a single soup. But guess what? America is not a mere soup, it's a bouillabaisse, and this is what attracted me to it in the first place. Well, we need to get into there and scuff up some of these notions and destroy the simplicities that people try to impose upon us. We're so much more intelligent than our political parties want us to be. Do you feel that tension in North Carolina?

Ron Rash: Oh, yes. Part of my frustration right now is that we allow ourselves these kinds of simplifications about who we are and what we are. It's easy to dismiss the power of empathy, but I don't know how we can possibly survive without at least some degree of it.

Colum McCann: Yes. Stories are muscular and strong. Stories are dangerous things: they can take away your reputation, they can take away your life. We have to be careful about stories and storytelling too. And stories are the way we navigate between the experience of one and another.

\section{NOTES}

1. https://www.powells.com/ The conversation is available at https://www.youtube.com/watch? $v=I C u j B 90 I s G g$. I want to thank Powell's Books for allowing me to transcribe and publish this conversation. My gratitude also goes to Ron Rash and Colum McCann, who have agreed to take a look at the transcript and made helpful suggestions.

2. Burning Bright was indeed awarded the Frank O'Connor award in 2010.

3. Paying homage to James Baldwin's celebrated 1963 non-fiction book, The Fire This Time, Randall Kenan's memoir The Fire Next Time was published in 2007.

4. https://narrative4.com/

INDEX

oeuvrecitee In the Valley, Serena, Let the Great World Spin, Apeirogon

\section{AUTHORS}

\section{FRÉDÉRIQUE SPILL}

Frédérique Spill is Professor of American literature at the University of Picardy-Jules Verne in Amiens, France, where she is also head of the research group UR UPJV 4295 CORPUS (https:// www.u-picardie.fr/unites-de-recherche/corpus/presentation/). She is the author of L'Idiotie dans 
l'œuvre de William Faulkner (PSN, 2009), soon to be published in English. She contributed to Critical Insights: The Sound and the Fury (Salem Press, 2014) and to Faulkner at Fifty: Tutors and Tyros

(Cambridge Scholars Publishing, 2014). She coedited The Wagon Moves: New Essays on As I Lay Dying, published in 2018 (L'Harmattan), as well as the spring 2018 issue of The Faulkner Journal. She has also published articles in French and in English on varied contemporary American authors including Flannery O'Connor, Cormac McCarthy, Robert Penn Warren, Jonathan Safran Foer, Nicole Krauss, Willa Cather, Russell Banks, Philip Roth, Toni Morrison, Elizabeth Spencer and Ron Rash. The Radiance of Small Things in Ron Rash's Writing was published by South Carolina Press in 2019. She's part of the editorial board of The Faulkner Journal. 